\title{
CHARACTERISTICS OF MALARIA PATIENTS WITH POSITIVE PARASITE AT DR. M. YUNUS HOSPITAL, BENGKULU
}

\author{
Dwi Putri Sulistiya Ningsih'), Mika Oktarina²), Violita Siska Mutiara3) \\ ${ }^{1)}$ Study Program of Public Health, School of Health Sciences \\ Tri Mandiri Sakti, Bengkulu, Sumatera \\ 2)Diploma III of Midwifery, School of Health Sciences Tri Mandiri Sakti, Bengkulu \\ 3) Diploma IV of Midwifery, School of Health Sciences Tri Mandiri Sakti, Bengkulu
}

\begin{abstract}
Background: Malaria eradication efforts become a global commitment to the Millennium Development Goals (MDGs) by 2015, then continue through Sustainable Development Goals (SDGs). Riskesdas 2013, the proportion of people with positive malaria reached $1.3 \%$ or about twice that of 2010 (0.6\%). In 2015, Bengkulu became one of the provinces in Sumatra with the highest Annual Parasite Incidence (API) number of 2.03. In 2016 there were 110 malaria sufferers with positive parasites who were hospitalized in Dr. M. Yunus Hospital, Bengkulu. This study aimed to describe the characteristics of malaria patients with parasite positive that were hospitalized at Dr. M. Yunus Hospital, Bengkulu, Sumatera.

Subjects and Methods: This was a descriptive case series study conducted in Dr. M. Yunus Hospital, Bengkulu, Sumatera. The study population was 110 malaria patients with a positive parasite that hospitalized in Dr. M. Yunus Hospital in 2016. A sample of 86 patients was selected for this study by simple random sampling. The independent variables were sociodemographic characteristics, parasite type, complication status, the average length of stay, circumstances of return time. The dependent variable was malaria. The data were collected from medical record and questionnaire.

Results: $20.91 \%$ malaria patients were 15 -24 years of age, $56.36 \%$ male, $22.6 \%$ pregnant women, 96\% Islam, 34.3\% self-employment, and $63.7 \%$ residence in the area of Bengkulu City. The highest proportion of parasite species was Plasmodium Vivax (94.4\%). Patients with $>1$ complication were $2.4 \%$. The average length of stay was 3.63 days. $42.3 \%$ hospital discharge state was healed.

Conclusion: The majority of malaria-infected men aged 15-24 years, who spent much time outdoors, and also pregnant women. Dr. M. Yunus Hospital, Province Health Office, and all related parties, are recommended to enhance health education, socialization of the active management, and malaria treatment.
\end{abstract}

Keywords: malaria, parasite positive, sociodemographic, characteristic

\section{Correspondence:}

Dwi Putri Sulistiya Ningsih. Study Program of Public Health, School of Health Sciences Tri Mandiri Sakti, Bengkulu, Jl. Hibrida Raya No.3, Bengkulu 38229, Sumatera. Email: dwiputri238@gmail.com Mobile: +6281377733346. 